\title{
Beckett and Bare Life: Post-war Political Subjectivity in
}

\section{Molloy}

\author{
Parker Evans \\ University of Alabama, USA
}

Copyright (c) 2019 by Parker Evans. This text may be archived and redistributed both in electronic form and in hard copy, provided that the author and journal are properly cited and no fee is charged for access.

\begin{abstract}
What can Beckett offer political theory concerned with subjecthood in the aftermath of the Nazi concentration camps? I suggest in this essay that Molloy provides a literary terrain through which to explore the collapse of the Enlightenment and the emergent vulnerability of the subject in relation to the state. Reading Foucault and Agamben's differing analyses of biopolitics through Molloy, I argue, offers an opportunity to critique both theorists as well an opportunity to read a theory of the post-camp subject into Beckett. I argue as well for a reading of Molloy as an illustration of Adorno and Horkheimer's critique of Enlightenment and the impossibility of political futurity under the logic of the camp.
\end{abstract}

Keywords. Beckett, Biopolitics, Sovereignty, Futurity, Camps.

Resumen. ¿Qué puede ofrecer Beckett a la teoría política relacionada con la subjetividad tras los campos de concentración nazis? En este ensayo sugiero que Molloy proporciona un terreno literario a través del cual se puede explorar el colapso de la Ilustración y la vulnerabilidad emergente del sujeto en relación con el estado. En este artículo se argumenta que la lectura de Molloy, considerando los diferentes análisis sobre biopolítica de Foucault y Agamben, ofrece una oportunidad de crítica hacia ambos teóricos así como una oportunidad de disponer de una teoría sobre el sujeto tras los campos de concentración en Beckett. Se sostiene, además, la lectura de Molloy como una ilustración de la crítica de Adorno y Horkheimer a la Ilustración y la imposibilidad del una noción de futuro político bajo la lógica de los campos.

Palabras clave. Beckett, biopolítica, soberanía, futuro, campos.

ISSN 1699-311X 
...but the man was innocent, greatly innocent, he had nothing to fear, though he went in fear, he had nothing to fear, there was nothing they could do to him, or very little.

Molloy

Beckett responded to the situation of the concentration camp - which, after the manner of a ban, he never names - in the only fitting manner ... not a word is said about the historical horror of our times.

Adorno $^{1}$

Published in 1951, Samuel Beckett's novel Molloy, the first of his Three Novels, is a disorienting a text that, like much of Beckett's oeuvre, disrupts conventional forms of narrative and narration. While this disruption of form makes compelling philosophical and stylistic challenges in its own right, I argue that Molloy can also be read as a historically situated attempt to grapple with how subjecthood and subjectivity have been themselves disrupted in the wake of the Second World War. The possibility of naked state violence against the exile or non-subject that Giorgio Agamben traces in Homo Sacer emerges undeniably ${ }^{2}$ in the concentration camp. This concept of "bare life" is, Agamben argues, crucial to the analysis of "biopolitics" that Michel Foucault begins to draw out in his History of Sexuality, Vol. 1. Molloy is demonstrably receptive to being read alongside theorists working through the idea of biopolitics and the transformation of governance in the post-war era, as the titular character fumbles his way through institutions that both inflict violence upon him and try to capture him as a subject of the state. As I will attempt to show, Molloy offers a terrain upon which different modes of governance, especially those that exist in the tension between sovereign and biopolitical power, are employed together without contradiction. This terrain of power that Beckett offers us through the character of Molloy both challenges and affirms the work of Agamben, Foucault, and other post-war theorists as they themselves contend with the collapse of a Western ${ }^{3}$ narrative of progress.

My focus is exclusively on the first half of Molloy, since the character of Molloy provides a consistent subject against which to place political theorists that are working through the same historical repercussions as Beckett. The Enlightenment's narrative of human progress is irreparably severed by the genocide enacted by the Nazis, an event with which almost all of the theorists I use contend explicitly. At points in this paper, it may be ambiguous as to whether I am subordinating these theorists to a reading of Beckett or vice versa. This is an intentional maneuver, as I hope to offer a critique useful both in complicating reductive moments in these theorists' claims as well as in arguing for an expressly political reading of Beckett. However, the first and second sections can be generally read as an application of theoretical frameworks to Beckett, while the final section can be read in terms of Beckett responding to and expanding upon Adorno and Horkheimer's critique of Western metaphysics. After a consideration of sovereign and biopolitical power in the first and second sections, I take up a reading of Molloy in the context of Dialectic of Enlightenment in the third section of this paper. I argue that Adorno and Horkheimer's connection between Enlightenment thought and the rise of fascism can and should be read alongside a biopolitical analysis by using Molloy as the central text. ${ }^{4}$ The post-war refusal, or perhaps inability, to look toward the future is reflected in Molloy's ultimately impotent sexuality, which can be read as both a biopolitical and metaphysical failure that responds to the devastation of the Holocaust.

Estudios Irlandeses, Special Issue 14.2, 2019, pp. 65-77. ISSN 1699-311X. Parker Evans. 


\section{Molloy the Political Subject: Sovereign Force and Ideology}

Molloy's encounter with a policeman is perhaps the most direct instance of Beckett engaging sovereign power in the novel. The episode is threaded with the signs of law, force, and identification - all of which turn back to the bodily subject which Molloy plays with comedic effect. The theatrical implication of performance here should be taken seriously, as Molloy's account of the exchange with the policeman is best read with attention to both the humor and discontinuities of the action. Molloy is first "hailed" by the policeman and through an undescribed "conversation" - which leaves open a possibility for anything from a Laurel-andHardyesque exchange of misunderstandings to actual violence - he comes to understand that he was in violation of a vague proper demeanor:

I heard myself hailed. I raised my head and saw a policeman ... What are you doing there? he said. I'm used to that question, I understood it immediately. Resting, I said. Resting, he said. Resting, I said. Will you answer my question? he cried. So it always is when I'm reduced to confabulation. I honestly believe I have answered the question I am asked and in reality I do nothing of the kind. I won't reconstruct the conversation in all of its meanderings. It ended in my understanding that my way of resting, my attitude when at rest, astride my bicycle, my arms on the handlebars, my head in my arms, was a violation of I don't know what, public order, public decency. (16)

In a moment of interpellation, the Althusserian sense of which I will return to below, Molloy must first acknowledge himself as a subject in response to his being hailed and positioned in relation to the law. The policeman's question immediately raises the issue of Molloy's reliability: Molloy takes what is likely a rhetorical question as a sincere one, but is keen enough to realize that there has been precedent in his life for a disjunction between the literal meaning of the question and the "reality" of its intent. As a result of this ambiguity, the authority of the policeman seems to revert to the tautological: he charges Molloy with resting because he can. The act of resting is itself the pretense for the sovereign decision; Molloy's crippled body is itself what violates "public order" and "decency," and therefore any act by that body is grounds for arrest. Molloy does not interpret the "conversation" in this way, and the absence of this part of the exchange is what leaves the policeman's articulation of Molloy's violation so dubious. There is no apparent significance in the force used by the policeman, which is exactly how Agamben characterizes the sovereign ban: "being in force without significance ... What, after all, is the structure of the sovereign ban if not that of a law that is in force but does not signify? ... But this is precisely the structure of the sovereign relation" (51). Molloy's narrative ambiguity - "I won't reconstruct the conversation in all of its meanderings" - makes a reading of the significance of the policeman's presence impossible outside of Molloy's interpretation. Inasmuch as Molloy cannot provide that significance, the threat of force that the policeman represents and later enacts is that sovereign force without significance. However, the very question of significance that Molloy raises through choosing what to include and exclude in his narration offers a dimension of subjecthood in the victim of sovereign force that Agamben does not yet confront. That is, does the victim of force interpret his situation such that he sees the intention of such violence as rejecting his subjecthood or calling him into it? Or perhaps there is a third position, for which we must turn now to Althusser's idea of calling and subjecthood to illustrate how Beckett creates a space that lies in between these two possibilities.

Estudios Irlandeses, Special Issue 14.2, 2019, pp. 65-77. ISSN 1699-311X. Parker Evans. 
At the same time that Molloy's interaction with the policeman functions within Agamben's theory of sovereignty and bare life, Althusser's theory of ideological subject creation provides a complementary reading of Molloy as a political subject. Althusser's account of interpellation fits neatly over Molloy's account of being accosted by the policeman, ending almost exactly where the passage above begins:

I shall then suggest that ideology "acts" or "functions" in such a way that it "recruits" subjects among the individuals (it recruits them all), or "transforms" the individuals into subjects (it transforms them all) by that very precise operation which I have called interpellation or hailing, and which can be imagined along the lines of the most commonplace everyday police (or other) hailing: "Hey, you there!" (Althusser 1269)

Althusser adds to Agamben's sketch of the sovereign subject the aspect of the subject's reaction to being hailed. Here, Molloy's response to the policeman is a corresponding component of the relationship between the sovereign force and the subject; whereas the subject's response does not appear in Agamben, Althusser demonstrates that the subject's existence is contingent upon that reaction to the policeman's hailing, inasmuch as subjecthood is being brought into confrontation with his existence apart from the other. Without the capacity for reaction to the sovereign power that the policeman represents, the subject, for Althusser, does not exist as such. ${ }^{5}$

Molloy's body provides a conjunction at which both Althusser and Agamben's conceptions of the subject can be examined further. The ideological manifests through action, as in the subject's self-conscious turn to face the policeman. Molloy's form of first-person narration is the extremity of interiority in a sense, but Beckett, as he is wont to do, ${ }^{6}$ has Molloy continually remind us that there is a body from which this speech comes. Althusser opens up his ideological analysis to this physicality when he argues that "the 'ideas' of the human subject exist in his actions ... inserted into practices. And I shall point out that these practices are governed by the rituals in which these practices are inscribed, within the material existence of an ideological apparatus" (1267). Molloy disrupts this ideological subject inasmuch as he does not exhibit "proper" behavior, but he also responds to the ideological exercise of the policeman. Althusser and Agamben meet here in the exercise of the law as a mode of subject creation, whether through force or coercion. Molloy differentiates between the significance of the law and its application when he says "to apply the letter of the law to a creature like me is not an easy matter ... It is better to leave things to the police" (20), but this is exactly the collapsing of legal signification into force that Agamben theorizes. Whether or not Molloy is a "good" subject in his exhibition of ideology, he is always vulnerable to "ideological apparatuses" as an embodied subject; in "[leaving] things to the police," he does not avoid the application of the law but becomes its most explicit subject. If the law is part of the text that ideology produces, and the application of the law by the policeman occurs in the form of physical force, then an ideological apparatus produces a reaction in Molloy even as he proposes that the police address him instead of the law. Ideology can take hold of him as long as it can enact itself forcefully on him. However, because Molloy distances himself from this force, he inhabits a subject-position that cannot be wholly subsumed by the policeman's ideological function. The subject's acknowledgement of the force being enacted upon him is a necessary part of that moment in which his subjectivity is conditioned. By avoiding narrative specificity, Molloy makes himself unavailable to the ideology that the policeman attempts to impose through force. Molloy both inhabits and complicates the subjectposition of homo sacer, since he is vulnerable to that force but also reactive to it. The exilic 
nature of homo sacer places the figure beyond the formal political boundaries of speech, but in "speaking" Molloy still gives the reader access to his subjectivity.

The narrative frame that Beckett provides for us through Molloy necessarily means that we have nothing but Molloy's word for what is "happening" in the sequence of events that he describes. If we assume that Molloy, as opposed to the narrators of The Unnameable, is an embodied subject in the world and not the unfolding of a linguistic exploration, figures like the policeman are "outside" of Molloy's internal narrative speech. And yet, however fraught the communicative gulf between Molloy and the policeman, they still operate within an ideological framework familiar enough to both that the policeman can hail Molloy and Molloy can recognize his subject-position. For Althusser, quoting St. Paul, "it is in the 'Logos,' meaning in ideology, that we 'live, move and have our being"' (1268). Molloy does not have a clear understanding of his relation to the policeman or the law, but he does indeed move well enough in that particular ideology that he hears himself hailed (16), and this is the minimum that ideology demands of the subject. Molloy remains tied to a sphere of bios, political life, as long as he can respond to such language. Molloy is indeed subject to the sovereign force that delineates bare life from the political sphere of bios, but his connection to the latter is not completely severed. ${ }^{7}$ As long as he has not been placed inside the structure of the camp, there is still the complication that the sovereign force's relation to the subject must be negotiated through that medium of bios.

To the extent that Molloy has speech, to the reader and to the policeman, he has not wholly fallen into the total state of exception that bare life represents. Although his relationship to the policeman, and therefore to sovereign force, is characteristic of the figure reduced to bare life, he is not yet entirely relegated to the exilic space that homo sacer occupies. This subjectposition is not in contradiction to Agamben's analysis but rather in support of the modern complexity of bare life's role in politics. While any modern political subject can be made vulnerable to sovereign force, absolute exclusion from the political sphere is no longer necessary for that force to be exercised. Indeed, this force transforms the political itself. Molloy encapsulates that complexity because he must respond to the entanglement of ideological and sovereign control, meaning that political power is invested in making him a subject who responds "properly" as well as one who is vulnerable to force. In order to properly evaluate that entanglement, we must turn to Foucault and biopolitics.

\section{“Charity kept me dying": Evading Biopolitics}

The modern turn from sovereign power which Foucault begins to investigate at the end of The History of Sexuality: Vol. 1 enables what he calls biopolitics: power is no longer defined as that which lets live and makes die, but that which lets die and makes live. The relation of power to the subject has developed into the extraction of life and labor, more than rule through the threat of death or corrective punishment. For Agamben, who continues this inquiry into biopolitics, this turn was made a political possibility by the ancient Greek distinction between zoё and bios. One can enter or be taken out of bios, the political sphere, but the fact of life, zö̈, always remains as a foundational component of being.

As Molloy says of himself, the application of the law to him is "not an easy matter," because, at least in Agamben's theoretical frame, Molloy seems to move across the boundary that homo sacer marks. He does not quite inhabit the political sphere of bios because he cannot properly participate in it, but he is not subject to the absolute sovereign ban which would treat him as excluded from bios because the policeman enters into a kind of negotiation with him, treating him as a kind of degenerate who is still within a formal jurisdiction of the state. Molloy's

Estudios Irlandeses, Special Issue 14.2, 2019, pp. 65-77. ISSN 1699-311X. Parker Evans. 
elusive political status plays across the line between zö̈'s vulnerability (to the force of the policeman) and the formalities of bios (identity papers). Additionally, Molloy's relation to the state is partially suspened by his relation to his mother. A fixture of his thought, she appears even as he is brought in by the policeman to the sergeant, in juxtaposition with another demand for identifying papers. Molloy is caught between the formal state apparatus and the biopolitical function of the family: "the sergeant, content to threaten me with a cylindrical ruler, was little by little rewarded for his pains by the discovery that I had no papers in the sense that this word had a sense for him, nor any occupation, nor any domicile, that my surname escaped me for the moment and that I was on my way to my mother, whose charity kept me dying" (18). Molloy is able to evade the agent of the state in his lack of documentation, job, home, a traceable family lineage, all of which are necessary to make him an identifiable subject, and therefore susceptible to control. This is a conception of subjectivity reliant upon a modernized understanding of bios: documentation, a job, a home (which is notably part of zö̈ in Agamben's reading of classical Greek theory), a surname; are all "proof" of the subject's participation in the public sphere. While still subject to interrogation by the policeman and the sergeant, Molloy does not - perhaps cannot - provide the handles of identification by which the state can take regulatory control.

Molloy's relationship to his mother is another vital point of biopolitical subjection. That his mother's charity "[keeps] him dying” might easily be excused as another of Molloy's grammatical peculiarities that reflects his cynical view on the pain of existence. The crippled state of his body reinforces the idea that the continuation of life is, for him, an excruciating process, and it makes sense that he might frame that continuation in terms of moving towards life's negation. While Molloy's focus is on the notion of dying, the implication is that he is being kept from its realization, and in a sense being made to live. So while there is no obvious figure of the state in this instance, as with the policeman, the power over making live and letting die is still present; Molloy evades the formal power of the sovereign in the policeman and the sergeant, but is held captive by the charitable power of his mother. And yet the sergeant, and by extension the state, also exercise this power through the social worker to whom they send Molloy. Once Molloy concedes that his mother's name is "very likely" also Molloy, ostensibly giving the sergeant a shred of identification by which to document him, he is taken away to a "guardroom" (19). Soon after, a woman whom he assumes to be a social worker hands him a "greyish concoction" and a "thick slab of dry bread." This meager fare is recognizable as the kind of sustenance served to keep a prisoner or a mental patient alive - a subject being made to live. Molloy indicates familiarity with encounters of this kind, warning the reader,

Let me tell you this, when social workers offer you, free, gratis and for nothing, something to hinder you from swooning, which with them is an obsession, it is useless to recoil, they will pursue you to the ends of the earth, the vomitory in their hands ... Against the charitable gesture there is no defence, that I know of. You sink your head, you put out your hands all trembling and twined together and you say Thank you, thank you lady, thank you kind lady. To him who has nothing it is forbidden not to relish filth. (19)

If Molloy's interpretation of events is reliable in this case, the police sergeant passes him from subjection to the law's force to the responsibility of the social worker's care. It seems plausible that Molloy has been in this situation and that he has likely been passed over to social workers before. Their "obsession" with preventing the patient - now a biopolitical trope - from "swooning" parallels Molloy's mother's charity which "[keeps] him dying." There is no apparent

Estudios Irlandeses, Special Issue 14.2, 2019, pp. 65-77. ISSN 1699-311X. Parker Evans. 
concern, in either kind of charity, for Molloy's well-being beyond its continuation; there is no allowance for death because death signals the end of a certain kind of power.

In his eleventh lecture in the series entitled "Society Must Be Defended" at the Collège de France, Foucault argues that, in contrast to the classical conception of sovereign power, biopolitics has no interest in or use for death: "now that power is decreasingly the power of the right to take life, and increasingly the right to intervene to make live ... death becomes, insofar as it is the end of life, the term, the limit, or the end of power too" (248). ${ }^{8}$ The episode with the social worker demonstrates this shift, as the force of the policeman gives way to the nauseating "charity" of biopolitics. There is a particular dimension to his interaction with the social worker that slips through Foucault's analysis, however, in Molloy's rejection of the food offered to him. Molloy recognizes a violation of his dignity in the way he is treated; he should be a vulnerable subject almost entirely stripped of agency, such that that he has no recourse, "no defence," against the miserable prolonging of his life. The acute line "to him who has nothing it is forbidden not to relish filth" is a pointed condemnation from an indignant, humanistic perspective, of what it means for subject to recognize his vulnerability to biopolitical control. Molloy's reaction is to fling the bowl of "vomitory" away, making sure to point out that "I did not let it fall, no, but with a convulsive thrust of both my hands I threw it to the ground ... far from me, with all my strength" (20). Like his failure or inability to make himself wholly available to the documentative power of the sergeant, Molloy disrupts a process of biopolitical power intent on making him suffer the "filth" of the social worker, although in this instance, he is insistent that this is a decision. Once again his narrative reliability comes into question as to his intention, but he evades the social worker's grip, intentionally or not. The particularity of this evasion, as opposed to his comically frustrating lack of information for the sergeant, comes from his disdainful rejection of the social worker's offering. Rather than succumbing through sheer miscommunication or indifference to the biopolitical imperative of staying alive for the sake of living, Molloy proves himself capable of recognizing, albeit in a roundabout way, the cynical disinterest which power has in him beyond the perpetuation of his bare life.

Foucault argues that one of the causes for the emergence of biopower was the gradual failure of the classical sovereign model to exercise control over a population. This model, "found itself unable to govern the economic and political body of a society that was undergoing both a demographic explosion and industrialization. So much so that far too many things were escaping the old mechanism of the power of sovereignty, both at the top and at the bottom, both at the level of detail and at the mass level" ("Society Must Be Defended" 249). The pricipal problem that biopower emerged to contain was precisely the "escape" Molloy makes. As opposed to the figure of the criminal that the sovereign model was prepared to accommodate, Molloy represents a subject who can, in some ways, escape classical sovereign power. The failure of the policeman to instill in Molloy self-reflective sense of fear in the face of force - as distinct from his denial or diminishing of the force exercised on him - demonstrates the passage from a power intent on subjugation of the body to power seeking access to the body. Foucault recognizes the complexity of biopower's navigation of state and institutional control, and he remarks on the relationship between the two, which he denotes as

an organic institutional set, or the organo-discipline of the institution, if you like, and, on the other hand, a biological and Statist set, or bioregulation by the state. I am not trying to introduce a complete dichotomy between State and institution, because disciplines in fact always tend to escape the institutional or local framework in which they are trapped. What is more, they easily take on a Statist dimension in apparatuses such as the police,

Estudios Irlandeses, Special Issue 14.2, 2019, pp. 65-77. ISSN 1699-311X. Parker Evans. 
for example, which is both a disciplinary apparatus and a State apparatus (which just goes to prove that discipline is not always institutional). (250)

Foucault's analysis of the police as a dual instrument of both disciplinary power and state regulation also complicates the role of the police in Althusser and implicitly in Agamben. To place Althusser's hailing by the police, the moment of interpellation par excellence, alongside Foucault's summation of the police's role adds both an ideological dimension to Foucault's biopolitics and a bodily vulnerability to Althusser's ideology. In this a way, Beckett creates a space in which the subjectivity which ideology produces necessarily exists simultaneously with the body in which biopolitics is interested in regulating.

Much like Agamben's work in Homo Sacer, Foucault's analysis of biopolitics leaves out a responsive subject, and understandably so. As biopolitics is concerned with the workings of the body, an analysis of it should not necessarily have to go beyond those identifiable functions. If the body is alive and reproducing correctly, it thereby allows power to continue to reproduce as well. But, as Althusser reminds us, ideology similarly needs "good" subjects to reproduce itself: 'the subjects 'work,' they 'work by themselves' in the vast majority cases, with the exception of the 'bad subjects' who on occasion provoke the intervention of one of the detachments of the (repressive) State apparatus" (1270). Althusser's framing of the "State apparatus" - the police, for example - as "repressive" can be taken in a way similar to Foucault's disciplinary model of the state. As Molloy's encounter with the policeman demonstrates, however, the discipline (or force) of the police is not its own end, and is rather an attempt to get him to "work" in the ideological sense and conform to whatever public order he is ostensibly violating. The power of the policeman, as with biopower, aims to make the subject properly functional. Molloy refuses the policeman this power when he does not properly convey the extent of the force used upon him; the ambiguity signals both the ideological failure to respond with fear to force and the failure to have regard for one's own bodily well-being. This disregard corresponds to the passive continuation of his life that Molloy finds in his mother's charity, but Molloy does not have the same passivity when it comes to the revolting offering of the social worker. There, Molloy exercises agency in prioritizing his revulsion over nourishment, revealing, perhaps, that biopolitics cannot wholly account for a subject whose personhood retains any concept of dignity, or, at the least, preference.

Molloy's repeated frustration of the powers that try to take hold of him mark him as a "bad subject" in both the ideological and biopolitical sense, but his position as such is only apparent when he is in proximity to those apparatuses of power. However, it is only a particular function of biopower that we see him evade in the case of the social worker. Foucault stresses, both in History of Sexuality, Vol. 1 and in "Society Must Be Defended", that the modern interest in sexuality is foundational to the development of biopolitics because of its obvious role in reproduction. In his eleventh lecture from "Society Must Be Defended", Foucault argues that, "because it also has procreative effects, sexuality is also inscribed, takes effect, in broad biological processes that concern not the bodies of individuals but the element, the multiple unity of the population. Sexaulity exists at the point where body and population meet" (251). If, as Foucault suggests, an emergent power defined by its relation to population rather than to the individual has become the dominant mode of control in modernity, biological reproduction is at the root of that power's concern. Deviant sexual behavior is no longer of interest as a matter of individual perversion, but as a threat to biopower; if power is now concerned with "making live," sex that does not involve the production of life must be controlled. What makes Molloy such an interestingly disruptive subject to biopolitical modes of control is not just his haphazard

Estudios Irlandeses, Special Issue 14.2, 2019, pp. 65-77. ISSN 1699-311X. Parker Evans. 
disruption of systems made to document and preserve his life, but his aversive relation to normative sexual activity. In regard to Molloy's relationship to sex, a more abstract analysis through and beyond biopolitics is necessary, especially in conjunction with the interplay between Enlightenment and bare life.

\section{Reproduction and Futurity}

Molloy's narrative is filled with references to his sexual peculiarities, and they are all crucially characterized by the improbability of resulting in reproduction. This characteristic is of interest to biopolitical power, but it also implies another political position which Molloy inhabits, or, more pertinently, represents. In terms of representation, I do not propose a metaphorical reading of Molloy's sexuality but rather a reading concerning the imaginative limits it presents. The analyses I give in the preceding two sections are crucial in understanding these limits, but reading biopolitics and sovereignty in Molloy do not sufficiently secure its historical position. The quote from Adorno which I use as an epigram for this paper is critical in understanding Beckett's relationship to a politics after the camps. I will return to Adorno below, with the frame he provides regarding how Beckett's work responds to the concentration camp by saying nothing about "the historical horror of our times" (qtd. in Durantaye 159); the absence of any direct reference to the camp gives the historical event of the Holocaust more weight than language can convey. By omitting the camp in the particular, it permeates the entirety of Molloy's narrative, reflecting Agamben's warning that the camp must not be taken as "a historical fact and an anomaly belonging to the past (even if still verifiable) but in some way as the hidden matrix and nomos of the political space in which we are still living" (166). Molloy lends itself to an examination of this political space even more effectively for the impossibility of Beckett having come into contact with this theoretical claim. By reading the threat of the camp as underlying all politics following the Holocaust, Molloy's failure to reproduce reflects a politics in which imagining a future seems to be an impossibility.

If, as for Foucault, sexuality in modernity "exists at the point where body and population meet," the biopolitical significance of sexuality is that it must ensure there will be a future population to be governed. Biopolitics and formal politics meet at the symbolic point of the future citizen, most often represented by the figure of the child. ${ }^{9}$ Molloy's sexuality is in contradiction to this political imperative, as his sexual preferences are almost exclusively those that would not result in reproduction, and his attitude toward sex is best characterized by indifference, as Paul Stewart points out in Sex and Aesthetics in Samuel Beckett's Work. Although Molloy seems to be slightly troubled by the particulars of his experiences, especially his uncertainty of the gender of his partners, he ultimately has little concern for any decisive memory: "Don't be tormenting yourself, Molloy, man or woman, what does it matter?" (51) Even this question seems to be asked with a shrug rather than an indiscriminate libido. An encounter with a woman, whose name he claims is either Ruth or Edith, has an outcome as ambiguous as the gender of his previously mentioned partner, since, although he recognizes that this partner is a woman, he recalled only that "she had a hole between her legs, oh not the bunghole I had always imagined, but a slit, and in this I put, or rather she put, my so-called virile member, not without difficulty, and I toiled and moiled until I discharged or gave up trying or was begged by her to stop" (51). While the first outcome might have had reproductive potential, Molloy does not use pleasurable language to describe his unlikely orgasm. A sexual act with a woman that is possibly reproductive is not an arousing event, as his remark about a "so-called virile member" indicates. 
Molloy's sexual activities, whether implied to be masturbatory, with a potentially infertile woman, or with another man, all occur without the likelihood of conceiving a child. In reference to Schopenhauer's quip that the unborn child is "already kindled in the meeting of [the lovers'] longing glances," Stewart writes that "once this telos has been removed, we are left with that mix of grotesque comedy and the clichés of love" that describe many of Beckett's characters generally, and certainly apply here to Molloy (95). Rather than a potential celebration or exploration of non-normative sexualities, Molloy's exploits read as failures of a tired sexual script. The encounter with Ruth/Edith is indicative of this, as Molloy seems to be following her lead with the understanding that she is showing him what love is, saying he gave himself to the sex "with a good enough grace, knowing it was love, for she had told me so" (52). The rest of the encounter is equally farcical, as Molloy spends time musing on whether they actually had anal sex and if so, whether it still counts as love. Certain "clichés of love" - that the sexual partners are a young man and woman, that they must be "lovers," that they could conceive a child - are all collapsed by Molloy and Ruth/Edith by a failure to live up to those clichés. Their encounter is made comedic by Molloy's confusion and dysfunction, rather than being a description of elderly and disabled people having sex (Ruth/Edith has rheumatism and lumbago and Molloy has a bad leg). It is important to make this distinction, inasmuch as it is might be tempting to read Beckett in terms of sexual liberation, for Molloy's sexual indifference and bodily familiarity should not be mistaken for a "progressive" development in sexual discourse. ${ }^{10}$ In fact, it is the failure of a discursive production to capture Molloy's sexuality which gives Molloy yet another political dimension.

As Stewart points out, there is a telos implied in a normative, procreative representation of sex which is not found in Molloy's sexuality. ${ }^{11}$ The underlying absence of a future has both existential and political significance if Molloy is maintained to be a political subject. The existential horror that Adorno and Horkheimer attempt to work through in Dialectic of Enlightenment, written during the Second World War, is tied closely to the (bio)political logics Agamben identifies as manifesting at the same time. While Agamben looks at the event of the camp through the historical development of biopolitics, Adorno and Horkheimer are writing as they watch fascism comes into political power. One of the central questions Adorno and Horkheimer ask, namely, how could fascism emerge out of a legacy of Enlightenment, is made more horrific by the discovery that the civilian space continued to exist alongside the genocidal space of the concentration camp. Adorno explores a political future after fascism - and new forms of fascism - in his later works, but Dialectic of Enlightenment does not yet ask these questions in quite the same way. Thus the immediate horror of Nazi Germany, that fascism and genocidal politics have been welcomed in, must be considered in conjunction with the post-war political problem of what to do with the fact that a population within the nation-state can be systematically exterminated. In the wake of a genocide carried out by the victims' own state, the potential for one's own extermination looms behind every subject.

After the final throes of Enlightenment's promise of progress, political subjectivity took on, as Foucault argues, a different kind of vulnerability to power through biopolitics. The existential and bodily condition in which the reader finds Molloy, literally unable to conceive of a future, is at the conjunction of the biopolitical imperative to grow the population through procreation and the collapse of a political narrative predicated on an inevitably better future. In Dialectic of Enlightenment, Adorno and Horkheimer write that "Enlightenment expels difference from theory. It considers 'human actions and desires exactly as if I were dealing with lines, planes, and bodies' [Spinoza]. The totalitarian order has put this to effect in utter seriousness" (67). The rigidity which Enlightenment thinking seeks out, which "expels difference" so that

Estudios Irlandeses, Special Issue 14.2, 2019, pp. 65-77. ISSN 1699-311X. Parker Evans. 
things may be neatly classified and thus dominated, foreshadows its political implications in the exclusionary politics of genocide. The Holocaust was, as Agamben's work argues, a manifestation of biopolitical logic, as well as proof that the Enlightenment's promise to "[liberate] human beings from fear and [install] them as masters," as Adorno and Horkheimer put it (1), harbored a much more horrific potential. The teleology implicit in that promise, that a society governed by reason would eventually better itself to the point of a "truly human state" (xiv), collapses in Molloy in such a way that responds to what it means to think about a political future after genocide.

Beckett is not engaged in metaphorically representing the camps or providing an analogy for their experience. Rather, Molloy's apathy toward his inability to conceive should present an imaginative limit can be read underneath his whole narrative. The absolute end of the concentration camp, unlike the work camp, freezes subjectivity in that space: there is nothing that can come after the concentration camp because it is its own end. In the political aftermath of the camps, they must recognized as a possibility, even if that possibility is used as a warning in political rhetoric. The realization that the nation-state's own subjects can be herded and exterminated in a quantity inconceivable even to juridical decision cements itself in the political imagination. Adorno's own remarks on Beckett's relationship to that historical space that comes "after Auschwitz" suggest that Beckett's writing is entangled in the struggle with that historical realization. In Beckett's Art of Mismaking, Leland de la Durantaye turns to fragments of Adorno's writing on Beckett to clarify this relationship, writing that

Adorno found that Beckett addressed the horrors of their times the only dignified way possible. He wrote that "Beckett does not even indict society. Precisely not and this is exactly the tip of the spear he aims at it" ... Auschwitz presented a problem for artists that Adorno saw Beckett as the first to truly address: by not saying a word. In Negative Dialectics Adorno wrote that "Beckett responded to the situation of the concentration camp - which, after the manner of a ban, he never names - in the only fitting manner ... In Beckett's novels, in which not a word is said about the historical horror of our times, I find this horror incomparably more precisely portrayed" than any work he knew ... For Adorno, Beckett did the noble thing - as a man and as an artist - which was to refrain from writing anything at all about the concentration camps (in which many close to him were murdered), and to write of absolutely everything else as though it were one. (159)

To write of everything as if it were the camp is to write of a world with no future. The lack of future represented in Molloy's grotesquely comedic failure to orgasm (or remember whether he did) is no climactic collapse of history but the whimper of an imaginative deterioration. Molloy's effective impotency finds its political reflection in the fact that the camp produces nothing, but also in the camp's lesson that the life of any subject can be stripped bare. When all subjects are in thrall to a politics structured by biopower, the camp is the ever-present apparatus for the ultimate exercise of political power, and thus all subjects stand in relation the camp: it becomes the definitive limit of the modern political imagination, and renders that imagination without future.

\section{Conclusion}

I would like to suggest, in conclusion, that Beckett can and should be read as a vital thinker of the post-war political aftermath. Beckett's political and philosophical thought is in bold conversation and contention with an entire legacy of European thinkers, and his irreverent but keen response to 
that legacy should in turn inform how we view the trajectory of Western thought. In concert with Adorno and Horkheimer's, as well as Agamben's, unveiling of the violent foundation of dominance in Western philosophy, Beckett provides textual terrain to explore its collapse. Subjectivity, now recognized in Beckett's work as profoundly conditioned by being a body, transforms the thinking subject into a living one who is vulnerable to the world. Beckett reveals that the subject in philosophy has always been a political one, and that the failure to acknowledge that relationship through the body has allowed much violence to slip past philosophy's notice, as well as for philosophy to tacitly endorse it. If the subject is a mind or a soul first, and a body second, what can be done to the body is not of primary concern. I will finish with the epigram from Molloy which begins this paper as an illustration of that anxiety of embodiment: "but the man was innocent, greatly innocent, he had nothing to fear, though he went in fear, he had nothing to fear, there was nothing they could do to him, or very little" (6). There is a biopolitical sensibility which shadows this statement, as political interests shift from the subject's innocence or guilt to what can be done to him. At the same time that Western politics debates what is to be done with these embodied subjects, philosophy has little response except horror, apathy, or perhaps only sheepishness in seeing that its preoccupation with the mind has left the body exposed. What Agamben reveals, with the separation of bare life and political life, is that the possibility of the camp seeded in the foundations of Western thought has finally turned back on the West. Beckett offers a way to recognize that desolation not as a fatalistic nihilism but as a world of our own making. It is, perhaps, too late in the development of our political imagination to dig ourselves out of the threat of bare life. But, Beckett shrugs, it has always been too late.

\section{Notes}

\footnotetext{
${ }^{1}$ Quoted in Stewart, 159.

2 This paper is written with the understanding that I fail to properly contextualize the violence of the Holocaust in regard to postcolonial theory, especially with regard to the arguments of Aimé Césaire and Frantz Fanon that Nazism was the deployment of colonizing techniques on Europe itself. Europe's self-reflexive horror at the camps should thus be framed as a collapse of a fantasy of European immunity to systematic eradication, rather than by a narrative of Nazism and the Holocaust grown in a two-decade span and detached from the colonial and Jim Crow lessons of racial ghettoization.

${ }^{3}$ I use "Western" to denote a series of debates and problems ranging from Ancient Greeks to the early twentieth century that is limited by the ontological primacy and the historical construction of Europe.

${ }^{4}$ As far as Beckett scholarship, I have yet to find a sustained critique that engages not only Foucault and Agamben's differing biopolitical analyses but also Adorno and Horkheimer's critique of Western metaphysics specifically in relation to Molloy. While there are certainly engagements within Beckett scholarship regarding each of these topics and theorists, my own argument is specifically positioned not only by collecting these frameworks around Molloy but also by approaching the politics of the novel independent of biographical analysis. Although Beckett's recorded experience in Nazi Germany, for example, offers a necessary contextualization of his following work, I suggest that the limits to such biographical context should be explored by putting his writings under explicitly political theoretical pressure. For example, chapter 3 of Emilie Morin's Beckett's Political Imagination approaches Beckett's postHolocaust writings in relation to the specific historical developments surrounding those works rather than their ontological implications. Both approaches, I believe, are necessary to begin to do Beckett's post-war works justice.

5 A necessary caveat here is that Althusser's account of ideological subject creation does not involve sovereignty, and therefore my own interjection of sovereignty bypasses a formal critical engagement with this problem.

${ }^{6}$ See McNaughton, chapter 5.

7 See Samuel Beckett and Testimony for David Huston Jones' use of Agamben to read the loss of "ontological security" in the Three Novels, especially pages 36-8.
} 


\footnotetext{
${ }^{8}$ This conception of biopolitics is notably different from that offered by Agamben in that Agamben is fixated on the sovereign as a figure preserved in biopolitical analysis. There are two likely reasons for this, one being that Agamben is largely arguing through a Schmittian conception of sovereignty and therefore reliant on a politics of the sovereign decision to relate bare life to biopolitics. Thus it is necessary for Agamben to include the sovereign figure to make sense of the exclusion from bios that bare life represents. A second and more practical reason is that Foucault's lectures at the Collège de France, which offer far more than the speculations on biopolitics at the end of History of Sexuality, Vol. 1, were transcribed and published after Agamben wrote Homo Sacer. Each mode of analysis is useful independent of the other, and the points at which they pull at each other provides a space for further critical investigation.

${ }^{9}$ I take this particular idea from Stewart's reference to Lee Edelman's work No Future: Queer Theory and the Death Drive.

${ }^{10}$ Stewart addresses Molloy's sexuality at the end of chapter 3 and in chapter 4 of Sex and Aesthetics. However, this analysis does not extend beyond the Molloy's complication of the language of sexual identity.

${ }^{11}$ See Stewart, 82, for an adjacent analysis of procreation and the future.
}

\section{Works Cited}

Agamben, Giorgio. Homo Sacer: Sovereign Power and Bare Life. Trans. Daniel Heller-Roazen. Stanford: Stanford University Press, 1998.

Althusser, Louis. "From Ideology and State Apparatuses." The Critical Tradition: Classic Texts and Contemporary Trends. Boston and New York: Bedford/St. Martin’s, 2007. 12631272.

Beckett, Samuel. Three Novels: Molloy; Malone Dies; The Unnamable. New York: Grove Press, 1958.

Foucault, Michel. "Society Must Be Defended”. Trans. David Macey. New York: Picador, 2003.

- The History of Sexuality, Volume I: An Introduction. Trans. Robert Hurley. New York: Vintage Books, 1990.

Horkheimer, Max and Theodor W. Adorno. Dialectic of Enlightenment: Philosophical Fragments. Ed. Gunzelin Schmid Noerr. Trans. Edmund Jephcott. Stanford: Stanford University Press, 2002.

Jones, David Huston. Samuel Beckett and Testimony. New York: Palgrave Macmillan, 2011.

McNaughton, James. Samuel Beckett and the Politics of Aftermath. Oxford: Oxford University Press, 2018.

Morin, Emilie. Beckett's Political Imagination. Cambridge: Cambridge University Press, 2017.

Stewart, Paul. Sex and Aesthetics in Samuel Beckett's Work. New York: Palgrave Macmillan, 2011.

Received: 7 May 2019

Revised version accepted: 12 September 2019

John Parker Evans is a masters student in women's studies at the University of Alabama. His research areas include classical political philosophy, global race studies, and critical theory.

jparkerevans@gmail.com

Estudios Irlandeses, Special Issue 14.2, 2019, pp. 65-77. ISSN 1699-311X. Parker Evans. 